\title{
Limits to Freedom of Speech in the Republic of Latvia During the Parliamentary Period (1918-1934)
}

\author{
Dr. iur. Elīna Grigore-Bāra \\ Faculty of Law, University of Latvia \\ Docent, Department of Theory and History of Law \\ E-mail: elina.grigore-bara@lu.lv
}

The article is dedicated to the analysis of one element of the constitutional identity of the Latvian State - freedom of speech - during the initial democratic period in the State's existence. The author analyses the rules on the protection of honour and supervision of the press as limits to freedom of speech. It is concluded in the article that the boundaries between one person's freedom of speech and another person's honour in the Republic of Latvia changed little compared to the previous period in the history of law and that honour as a legal benefit was prized more highly. The framework of freedom of the press, in turn, was constantly expanded. However, the creation of the lists of prohibited books and third-rate and obscene literature proves that the State did not rely on individuals exercising freedom of speech properly. Paternalistic treatment of its citizens was not unknown to the new democratic republic.

Keywords: freedom of speech, freedom of the press, legal protection of honour, constitutional law, penal law.

\section{Contents}

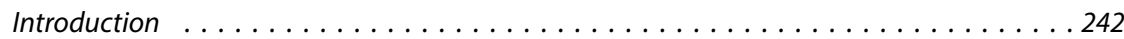

1. Constitutional Framework of Freedom of Speech . . . . . . . . . . . . . . . . . . . 243

2. Protection of Honour as the Limitation to Freedom of Speech . . . . . . . . . . . . . . 245

2.1. Delimiting Freedom of Speech and a Person's Honour in Penal Law . . . . . . . . 246

2.2. Delimiting Freedom of Speech and a Person's Honour in Civil Law . . . . . . . . 249

3. Legal Framework for Freedom of the Press . . . . . . . . . . . . . . . . 251

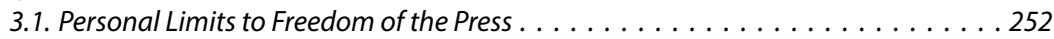

3.2. The Substantial Limits to Freedom of the Press . . . . . . . . . . . . . . . . . 254

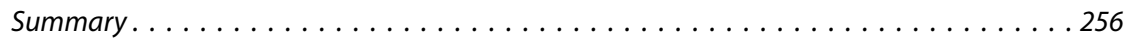

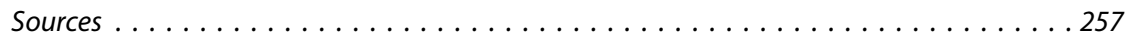

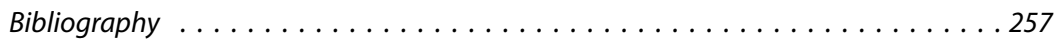

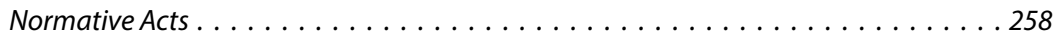

Other Sources . . . . . . . . . . . . . . . . . . . . . . . . . . . . 259 


\section{Introduction}

Freedom of speech is one of the civic freedoms and a person's fundamental right. However, it is not only a public subjective right, it is, simultaneously, also a constitutional value, reflecting the society's value judgements in a certain period. Within the framework of this article, the author studies the limits to freedom of speech as one of the elements in the selfhood of the Latvian State, which reveal the understanding of values and law in the Latvian society during the initial stage of the existence of the State of Latvia.

Latvia's statehood is based on the state continuity doctrine. The occupation of Latvia by the USSR did not terminate the existence of the Latvian State but only significantly limited its capacity. ${ }^{1}$ The State of Latvia was established as a legal person on 18 November 1918 and it continues to exist. Thus, the selfhood of the State today and in the interwar period is the same. The State's selfhood could be studied from the perspective of Hans Kelsen's concept of the basic norm ${ }^{2}$ or could be examined as the constitutional identity of the State. ${ }^{3} \mathrm{H}$. Kelsen defended a purely legal concept of the state, contending that the state and the legal system were identical concepts as to their content. ${ }^{4}$ The state exists as a legal order. ${ }^{5}$ The constitutional identity, in turn, is understood as the fundamental values and basic principles of a nation state. ${ }^{6}$ It unites the nation on the level of consciousness and the legislator may enshrine it legally in the constitution and laws. ${ }^{7}$ Although the second approach points to broader (not purely legal) sources of the state's selfhood, they both share at least two significant features. Both perspectives implicitly envisage that the State's identity is revealed also in regulatory enactments, and both recognise the dynamic nature of the State's selfhood. H. Kelsen writes that the basic norm is the grounds for creating or applying legal norms, giving a formally dynamic nature to the legal system. Separate provisions of the legal system cannot be logically derived from the basic norm through deduction. The creation or application of a legal norm is an act of will rather than of thinking. ${ }^{8}$ Thus, neither is identity a static category, it may develop and expand over time because it is open to the subject's experience. ${ }^{9}$

1 See more: Nepārtrauktỉbas doktrīna Latvijas vēstures kontekstā [The State Continuity Doctrine in the Context of Latvia’s History]. Collective of authors, scientific ed. Prof. Jundzis, T. Rīga: Latvijas Zinātṇu akadēmijas Baltijas stratēǵgisko pētijumu centrs, 2017.

2 Lazdiňs, J. Rechtspolitische Besonderheiten bei der entstehung des lettischen Staates und seiner Verfassung. Journal of the University of Latvia. Law, No. 7, 2014, p. 10.

3 Osipova, S. Tautas gars, pamatnorma un konstitucionālā identitāte [The Spirit of the Nation, Basic Norm, and the Constitutional Identity]. In: Osipova, $S$. Nācija, valoda, tiesiska valsts: celāa uz rìtdienu [Nation, Language, Rule-of-Law State: Towards Tomorrow]. Rìga: Tiesu namu aǵentūra, 2020, pp. 38, 39.

4 Schöbener, B., Knauff, M. Allgemeine Staatslehre. 2. Aufl. München: Verlag C. H. Beck, 2013, S. 75.

5 Kelsen, H. Reine Rechtslehre. Studienausgabe der 1. Auflage 1934. Herausgegeben von Jestaedt, M. Tübingen: Mohr Siebeck, 2008, S. 127.

6 Osipova, S. Tautas gars ... [The Spirit of the Nation ...], p. 40.

7 Osipova, S. Latvijas Republikas konstitucionālā identitāte Satversmes tiesas spriedumos [The Constitutional Identity of the Republic of Latvia in the Constitutional Court's Judgements]. In: Osipova, S. Nācija ... [Nation ...], pp. 45, 48.

8 Kelsen, H. Reine Rechtslehre, S. 74-75.

9 Konstitucionālo tiesību komisijas viedoklis "Par Latvijas valsts konstitucionālajiem pamatiem un neaizskaramo Satversmes kodolu" [Opinion of the Constitutional Law Committee "On the Constitutional Foundation of the State of Latvia and the Inviolable Core of the Satversme"], paragraph 65, p. 24. Available: http://blogi.lu.lv/tzpi/files/2017/03/17092012_Viedoklis_2.pdf [last viewed 20.03.2021]. 
The author aims to research the understanding and the course of development of one element forming the constitutional identity of the Latvian State - freedom of speech - in the initial democratic stage (parliamentary period) of the State's existence, insofar it is revealed in regulatory enactments. By revealing the dynamics of the constitutional identity, its internal diversity becomes evident, which allows taking a broader perspective on the possible solution to the present problems.

The status of freedom of the press and freedom of speech as elements of constitutional identity is confirmed by the fact that those were the first two freedoms mentioned in the founding act of the Republic of Latvia - Part V of the Political Platform "Civil Liberties". ${ }^{10}$ Such a choice necessarily follows from the idea of a democratic republic, because freedom of expression is a necessary precondition for free elections. The significance of free elections is revealed by the laconic words of the introductory part to the Latvian Constitution adopted in 1922 - "The people of Latvia in their freely elected Constitutional Assembly have decided to have such a national Constitution."11

As in the Political Platform, also in the second provisional constitution Article 9 of the Provisional Regulation on the Order of the Latvian State of 1 June 1920 , freedom of the press is named alongside freedom of speech. ${ }^{12}$ The concept of freedom of the press is no longer included expressis verbis in Article 100 of the Satversme of the Republic of Latvia; however, the contemporary fundamental rights dogmatics assumes that the concept of freedom of speech is broader and includes also the concept of freedom of the press as one of the ways, in which freedom of speech is manifested.$^{13}$ Moreover, the same approach to formulating the constitutional guarantees for freedom of speech was used both in the Fundamental Laws of the Russian Empire of 1906 and the unadopted Part II of the Satversme of the Republic of Law. Therefore, the author will research these two freedoms, named separately in the Political Platform and the Provisional Regulation on the Order of the Latvian State, together, as two ways whereby freedom of speech manifests itself.

\section{Constitutional Framework of Freedom of Speech}

Four civic freedoms were enshrined in the First Provisional Constitution of Latvia, i.e., the Political Platform: freedom of the press, speech, assembly and association, which had to be ensured by the Provisional Government Regulations. Five other freedoms were added to these four in the Provisional Regulation on the Order of the Latvian State: inviolability of a person, home and correspondence, as well as freedom of conscience and freedom to strike. These freedoms had to be ensured and established by respective laws. A comparison of both provisional constitutions reveals that the legislator rather than the executive power (the government) was entrusted with the establishment of civil freedoms. This, of course, is linked to the changes in the political situation as the outcome of the War of Independence. However, the substantive certainty of freedom of speech did not change, the wordings were equally laconic.

Pagaidu Valdības Vēstnesis, No. 1, 14(1).12.1918.

11 Valdības Vēstnesis, No. 141, 30.06.1922.

12 Valdības Vēstnesis, No. 123, 03.06.1920.

13 Kučs, A. Komentārs Satversmes 100. pantam [Commentary on Article 100 of the Satversme]. In: Latvijas Republikas Satversmes komentāri. VIII nodaḷa. Cilvēka pamattiesības [Commentaries on the Satversme of the Republic of Latvia. Chapter VIII. Fundamental Human Rights]. Collective of authors, scientific ed. Prof. Balodis, R. Rīga: Latvijas Vēstnesis, 2011, pp. 343-344. 
To reveal how freedom of speech was understood at the time, the draft Part II of the Satversme needs to be examined. The intention had been to guarantee freedom of speech in Article 94, Part II of the Satversme. Two versions of this article were submitted for discussion. The first one provided: "The citizens shall have the right, within the limits of law, to express their conviction in speech, writing, drawings and other forms of expressions. This right may not be denied in service and employment relationships". The second version included an additional sentence: "Censorship shall not exist in Latvia." 14 This wording of the fundamental right did not cause extensive discussions at the Constitutional Assembly. Apart from the rapporteurs, only two other deputies took the floor at the plenary session Markuss Gailitis, representing the non-partisan group of landless peasants and smallholders, and social democrat Fēlikss Cielēns. M. Gailītis supported the second version of Article 94 but proposed expanding it, following the model of the German constitution. F. Cielēns, in turn, proposed deleting from the article the words "within the limits of law" and introducing the principle that only the court could make someone liable for criminal offences in the press. ${ }^{15}$ Within the Satversme's Committee itself, opinions differed as to which version should be supported. One of the rapporteurs, Andrejs Kuršinskis, on behalf of one part of the Committee, defend the second version to emphasize that censorship normally did not exist, thus highlighting the exceptional nature of Article 117 of the Satversme. Co-rapporteur Jānis Purgalis, however, insisted that censorship was necessary in some cases, therefore, the first version should be supported. It is significant that President of the Constitutional Assembly Jānis Čakste, putting these two proposals for vote, called the second version "more radical". The Constitutional Assembly dismissed the proposals made by both F. Cielēns and M. Gailitis, as well as the entire second version of Article $94 .^{16}$ The choice of such formulation of freedom of speech is evidence of a strong conviction that limits to freedom of speech should be set also in a democratic republic and, thus, censorship was not deemed to be a legal institution that should be categorically denied.

Limits to freedom of speech, intended in the Satversme, were defined also in Article 117 of the Satversme, which authorised the Cabinet, during the state of exception, to suspend or restrict the application, inter alia, of Article 94, in the scope defined in a special law. ${ }^{17}$ Two elements in this legal norm require attention. Limiting freedom of speech in certain cases was again placed in the competence of the executive power, and it was also assumed that this fundamental right even could be suspended. Thus, the Latvian Constitutional Assembly did not regard freedom of speech as universal civic freedom, which should be ensured both in times of peace and times of war, but envisaged instead that, in cases of certain threats, freedom of speech could be given up altogether, although temporarily.

14 Satversmes sapulces V sesijas 2. sēdes (1922. gada 18. janvārī) stenogramma [Transcript of the $2^{\text {nd }}$ sitting of V session of the Constitutional Assembly (18 January 1922)], p. 535. Available: http://flriga. lu.lv/tzpi/materiali/Satversmes_sapulces_stenogrammas.pdf [last viewed 20.03.2021].

15 Ibid., pp. 535-536.

16 Satversmes sapulces V sesijas 2. sēdes (1922. gada 18. janvārī) stenogramma [Transcript of the $2^{\text {nd }}$ sitting of V session of the Constitutional Assembly (18 January 1922)], pp. 536-538.

17 Latvijas Republikas Satversmes 2. daḷa. Pamatnoteikumi par pilsoṇu tiesībām un pienākumiem (netika pienemta) [Part 2 of the Satversme of the Republic of Latvia. Fundamental Rules on Citizens' Rights and Obligations (was not adopted)]. In: Šilde, Ā. Latvijas vēsture. 1914-1940. Valsts tapšana un suverēnā valsts [The History of Latvia. 1914-1940. Formation of the State and the Sovereign State]. Stokholma: Daugava, 1976, p. 704. 
Article 94 of the Satversme repeated almost verbatim the first part of Article 118 of the Constitution of the German Reich, ${ }^{18}$ Article 117, however, was closer to Article 41 of the Fundamental Laws of the Russian Empire. ${ }^{19}$ During the debates of the Constitutional Assembly, rapporteur J. Purgalis explained that in all countries in certain emergency situations the possibility to restrict the civic freedoms in the interests of national security was envisaged. ${ }^{20}$ Most probably, the recent experience of World War I and the Latvian War of Independence had reinforced the conviction that in an emergency (war) situation restricting or even suspending an individual's freedoms was inevitable or, at least, useful.

The formulation of freedom of speech in draft Part II of the Satversme (as in the Fundamental Laws of the Russian Empire and the Constitution of the German Reich) included the clause "within the limits of law" - citizens were granted rights only within the limits of law. Jānis Pleps has explained that the authorisations to the legislator, included in the text of Part II of the Satversme, should not be considered as being clauses on the restrictions on fundamental rights but rather as further legislative plans. ${ }^{21}$ In assessing the meaning of the clause "within the limits of law", one can conclude that, primarily, the decision on the aims or expedience of freedom of speech was recognised as being in the discretion of the State and not an individual. Freedom of speech was not regarded as a citizen's natural right but as a subjective public right granted by the State, which existed only within the limits defined by the State. This wording reflected the understanding of an individual's right as created by the State, not existing naturally or supranationally. Hence, the State had greater discretion in creating the legal regulation on freedom of speech. The State was not obliged to justify interference into a person's freedom since its existence outside the framework defined by law was not even recognised.

\section{Protection of Honour as the Limitation to Freedom of Speech}

Pursuant to Immanuel Kant's philosophy of law, the general law on rights envisaged a person's freedom of external actions, which was compatible with the freedom of others in accordance with the general law. ${ }^{22}$ Hence, also the limits

18 "Artikel 118 (1) Jeder Deutsche hat das Recht, innerhalb der Schranken der allgemeinen Gesetze seine Meinung durch Wort, Schrift, Druck, Bild oder in sonstiger Weise frei zu äußern. An diesem Rechte darf ihn kein Arbeits- oder Anstellungsverhältnis hindern, und niemand darf ihn benachteiligen, wenn er von diesem Rechte Gebrauch macht." Die Verfassung des Deutschen Reichs ["Weimarer Reichsverfassung”] vom 11. August 1919. Available: http://www.documentarchiv.de/wr/wrv.html [last viewed 23.03.2021].

19 41. Iz“jatija iz dejstvija izlozhennyh v sej glave postanovlenij v otnoshenii mestnostej, ob“javlennyh na voennom polozhenii ili v polozhenii iskljuchitel'nom, opredeleny osobymi zakonami [41. Exceptions from the validity of the regulations set forth in this chapter in relation to areas declared under martial law or in a state of exception are determined by special laws]. Complete collection of laws of the Russian Empire - Vol. XXVI, No. 27805. Available: http://www.hist.msu.ru/ER/Etext/apr1906.htm [last viewed 20.03.2021].

20 Satversmes Sapulces V sesijas 10. sēdes (1922. gada 7. februārī) stenogramma [Transcript of the $10^{\text {th }}$ sitting of V session of the Constitutional Assembly (7 February 1922)], pp. 738-739. Available: http:// flriga.lu.lv/tzpi/materiali/Satversmes_sapulces_stenogrammas.pdf [last viewed 20.03.2021].

21 Pleps, J. Komentārs Satversmes 116. pantam [Commentary on Article 16 of the Satversme]. In: Latvijas Republikas Satversmes komentāri. VIII nodaḷa. Cilvēka pamattiesības [Commentaries on the Satversme of the Republic of Latvia. Chapter VIII. Fundamental Human Rights]. Collective of authors, scientific ed. Prof. Balodis, R. Rīga: Latvijas Vēstnesis, 2011, p. 752.

22 Rubenis, A. Imanuels Kants. Kerras stūmēja mēǵinājums tuvoties karalim [Immanuel Kant. The Wheelbarrow Pusher's Attempt to Approach the King]. Rìga: Minerva, 2006, p. 212. 
to freedom of speech should be marked in the place where the freedom of other persons begins. However, the peculiarity of freedom of speech is that it does not come up against the others' freedom of speech (these, to a certain extent, may even overlap or exist in parallel) but against the other persons' honour. The scope of an individual's freedom of speech depends upon the honour of another person.

Long before the constitutional safeguards for freedom of speech were adopted, a person's honour had been recognised as a value under legal protection. With respect to a person's honour, the boundaries of freedom of speech are broader and also vaguer compared to the procedure when the scope of freedom of speech is defined in law. Broader, because freedom of speech, until it does not injure a particular person and, thus, does not cause damage, is not limited at all. The vagueness, in turn, is linked to the possible difficulties in forecasting, whether a person will regard the particular statement as offensive. The fact that the limits to freedom of speech have been violated becomes apparent only in the particular case - at the moment when another person has felt defamation and turns to court. To be fair, it must be added that defamation and insult were not based on purely subjective, i.e., the victim's own, perception of honour. Professor Pauls Mincs has explained in the case of an insult the matter is not of a whim, injured selfishness and the victim's excessive sensitivity in assessing the events but such action by the perpetrator that would have offended an average person of the same cultural level and in the same circumstances. ${ }^{23}$ This, i.e., the criminal law system for delimiting honour and freedom of speech, has two additional important features: the limits to freedom of speech are individualised (more adapted to each individual case) and are based on the effectiveness of other kinds of social norms (in particular, morals) in society. Admittedly, with the changing role of morals as a social regulator and growing diversity of opinion in society, such limitation to freedom of speech would become vaguer and harder to predict.

Initially, the declaration of freedom of speech on the constitutional level did not impact the legal regulation on protecting a person's honour. During the period researched, there were two mechanisms for the protection of personal honour in the Republic of Latvia - of the criminal law or the civil law, and, hence, also three most important regulatory enactments that defined the limits to freedom of speech in this regard. Primarily, the protection of honour was exercised within the framework of penal law. Penal laws defined the boundary between one person's freedom of speech and the other person's honour. Two Penal Laws were in force in the Republic of Latvia during the interwar period. Pursuant to "Provisional Regulation on Latvian Courts and Procedure for Administering Justice" 24 of 6 December 1918, the Penal Laws of the Russian Empire of 22 March 1903 were introduced in Latvia and the new Penal Law entered into force on 1 August 1933. Whereas the civil law boundaries between freedom of speech and personal honour followed from Part III of the Collection of Baltic Local Laws or the Baltic Civil Law.

${ }^{23}$ Mincs, P. Krimināltiesības. Sevišķā dal̦a [Criminal Law. Special Part]. With Commentaries by Liholaja, V. Rīga: Tiesu namu aǵentūra, 2005, p. 302.

24 Pagaidu Valdìbas Vèstnesis, No. 1, 14.(1.)12.1918. 


\subsection{Delimiting Freedom of Speech and a Person's Honour in Penal Law}

The Penal Law of 22 March 1903 was applicable throughout almost the entire parliamentary period of Latvia. ${ }^{25}$ Chapter 28 of the law defined criminal offences against person's honour - 12 articles altogether (Art. 530-540 1 ). Moreover, only one of them, i.e., Article $540^{1}$ (on appropriation of a person's name) was adopted in 1925 by the Latvian legislator, but one more (Art. 532.p.) had been amended in 1906. Until 1933, the remaining ten articles were in force in their initial wording; i.e., that of 1903. This indicates that, in this respect, law of the Russian Empire did not cause a collision with the legal system of a democratic republic.

Following more than thirteen years of drafting the new penal law and postponing the entry into force of the new law several times, on 16 June 1933, the Saeima adopted the Law on Introducing the Penal Law and the Law on Disciplinary Punishments, providing that the Penal Law would enter into force on 1 August 1933. ${ }^{26}$ Chapter 32 of the new law "Defamation" consisted of 11 articles - Art. 508518. The wording and sanctions of some articles had been amended; however, the Latvian legislator had not introduced conceptual changes in this area. In analysing the new Penal Law, Arveds Švābe had established that only 53 articles of the total 584 , i.e., approximately $9 \%$, were entirely new. This can be explained by the fact that the main source for the new law was the previous Penal Law of $1903 .{ }^{27}$ Comparing the liability for injuring honour and libel, defined in both laws, also Diāna Hamkova has concluded that the regulation had been quite similar. She points out one innovation - criminal law liability was aggravated if the injury had been done by publishing systematically in a periodical offensive information about the private and family life of certain persons and if the editor or publisher of the periodical had been recognised as being liable for it. ${ }^{28}$ It needs to be added that also in this case the elements of the criminal offence had been defined already in the initial wording of the law of 1903. However, these elements of the criminal offence were transferred from Chapter 15 of the previous law "Violation of the regulations on supervising printing-houses or other printing facilities, the press, libraries, reading rooms and performances" and, thus, a crime to be prosecuted in public procedure had turned into a private delict, subject to the procedural rules of private charges. ${ }^{29}$

In view of the fact that the regulation on the protection of honour of the two laws does not differ significantly, the author will examine them jointly. The Penal Laws set out liability for two types of injuries to honour: personal insult (Art. 530 of 1903 Law; Art 508 of 1933 Law) and defamation (Art. 531 of 1903 Law; Art. 508 of 1933 Law). Personal insult was an intentional personal injury of honour or derogation

25 1903. gada 22. marta Sodu likumi. Tulkojums ar paskaidrojumiem un ar motiviem par Latvijas valdības laikā izdotiem grozījumiem. Tieslietu ministrijas sevišķas komisijas sagatavojumā [Penal Laws of 22 March 1903. Translation with explanation and reasons for amendments introduced during the period of the Latvian Government. Prepared by the special committee of the Ministry of Justice]. $3^{\text {rd }}$ edition. Rìga: Valsts tipogrāfija, 1930.

26 Valdības Vèstnesis, No. 138, 27.06.1933.

27 Švābe, A. Mūsu sodu likumu valoda [Language of our Penal Laws]. Tieslietu Ministrijas Vēstnesis, No. 6-8, 1933, pp. 139-140.

28 Hamkova, D. Goda un cieņas krimināltiesiskā aizsardzība. Promocijas darbs [Doctoral thesis "Criminal Law Protection of Honour and Dignity"]. Rīga: Latvijas Universitāte, 2009, p. 74. Available: http://dspace.lu.lv/dspace/bitstream/handle/7/5038/13775-Diana_Hamkova_2009. pdf? sequence $=1$ \&isAllowed $=y$ [last viewed 21.03.2021].

29 1933. gada 24. aprīḷa Sodu likums ar likumdošanas motīviem un sīkiem komentāriem [Penal Law of 24 April 1933 with Legislative Reasoning and Detailed Commentaries]. Complied by Mincs, P., Ehlerss, H., Jakobi, P., Lauva, J. Repeated edition. Rīga: SIA “Grāmata”, 2016, p. 158. 
of a person, disrespectful treatment of them, whereas an important element in the offence of defamation was spreading information that injured a person's honour, i.e., lowering a person's respect in the eyes of other persons. ${ }^{30}$ If an offending, derogatory or humiliating opinion was intentionally stated, the act could be qualified as an insult, while if information was spread, i.e., facts that had injured the plaintiff's honour had been disclosed to another person, the act already could be qualified as defamation. The analysis of these two types of injuries to honour reveals a difference in two respects, i.e., in the private (personal) or public nature of the injury and the injury's link to the truth.

Professor P. Mincs wrote that in the case of insult a person's sense of self-respect was injured, causing them mental suffering. ${ }^{31}$ An anonymous author who wrote in the Herald of the Ministry of Justice explained that, in the case of insult, a person's self-respect or subjective honour is injured. ${ }^{32}$ Thus, this offence, essentially, is aimed at the person himself or herself, their integrity and self-esteem. Therefore, in the case of insult, it was not important, whether the injury had occurred in public or private. Privately made statements also were punishable if it was proven that they were insulting and that the perpetrator had intended to injure the other person's honour or, at least, had been indifferent towards the consequences of his actions. For example, in a case of 1925, the court recognised that also sending an insulting letter had to be qualified as an insult. However, an insult in absentia was not punishable. In insult cases, the truthfulness of the statements was not significant. Thus, an opinion that was based on genuine facts but was insulting was recognised as being criminally punishable. ${ }^{33}$

The elements in the crime of defamation were aimed at protecting a person's good name (reputation) and public assessment (respect in the eyes of others). Thus, the elements of this offence no longer included the requirements that the victim had been personally addressed, it was, though, important to identify the unlawful disclosure of such circumstances that could cause a third person's derogation or disrespect towards the victim. Essential characteristics were the public nature of statements (the publicity condition) and the facts made public (not solely an opinion). ${ }^{34}$ In the case of defamation, it was possible to free oneself from liability if the accused proved that the disclosed information complied with the truth (exceptio veritatis) or if he had sufficient grounds to consider the disclosed circumstance as being true and he had done for the good of the State or society, in the interests of performing his duty, or in protecting his own or his family's honour. The defence of truth disclaimer, though, was meaningless if the disclosed information pertained to the leader of a foreign state or a foreign diplomatic representative in Latvia or the injured person's private or family life. ${ }^{35}$ In this regard, P. Mincs characterised the evolution of the elements of defamation. First of all, the punishment was envisaged for slander, i.e., intentional disclosure of untrue information that could injure the

30 K. V. Goda aizskaršana [Injury to Honour]. Tieslietu Ministrijas Vēstnesis, No. 9, 1926, pp. 356-357.

31 Mincs, P. Krimināltiesības ... [Criminal Law ...], p. 302.

32 K. V. Goda aizskaršana [Injury to Honour], p. 356.

33 Sodu likums ar komentāriem - izvilkumiem no Senāta Kriminālā kasācijas departamenta spriedumiem un ar alfabētisko un salīdzināmiem rādītājiem [Penal Law with Commentaries Extracts from the Judgements by the Senate Criminal Cassation Department with an Alphabetic and Comparative Indexes]. Complied by Mincs, P., Lauva, J. $2^{\text {nd }}$ edition. Rīga: Valsts tipogrāfijas izdevums, 1938, pp. 250-251.

34 Mincs, P. Krimināltiesības ... [Criminal Law ...], pp. 303-304.

35 Articles 537, 538 of the Penal Law of 1903; Articles 515, 516 of the Law of 1933. 
victim's honour in the eyes of third persons. If the accused was able to prove the truthfulness of the disclosed information, he was released from the punishment. This construction was based on the opinion that anything that complied with the reality could be freely discussed. However, this construction, which the professor deemed to be primitive, was gradually replaced by the concept of defamation, which envisaged linking the punishment with the nature of disclosed information. This approach followed from the assumption that society is not at all interested in having all ugly and bad things becoming public without sufficient grounds. ${ }^{36}$

The Penal Law tolerated insults, i.e., did not recognise as being punishable, in several cases - in family relations and in relations that were based upon disciplinary power. Children could not bring complaints against their parents; however, the courts have had assessed differently the cases of insult between married spouses. For example, in 1923, a case recognised that married spouses had common interests and the need of mutual yielding, which made the injury of honour inconceivable. In married relationships, only insult that was combined with actions of violent nature was said to be punishable. ${ }^{37}$ However, already in 1935, a court concluded that the law did not provide exceptions with respect to married spouses and, thus, one spouse could submit a claim against the other if honour was injured. ${ }^{38}$ Similarly, punishment was not impending also in those cases where the accused had disciplinary power and he, in exercising it within reasonable boundaries, had humiliated someone. A certain official position extended the boundaries of a person's freedom of speech. For example, a priest could instruct and scold members of his congregation. Thus, in 1929, a court reviewed a case, in which a Catholic priest was accused of addressing the plaintiff, who had entered the church in a short-sleeved and low-necked dress, by saying: "You, there, starkers, go dress yourself!" The court recognised that in this case the Penal Law was not applicable. ${ }^{39}$

In broadening the boundaries of certain persons' freedom of speech, accordingly, the level of protection of their honour was raised both in the cases of insult and defamation. The Penal Law of 1903 listed expressis verbis four groups of persons entitled to this higher level of protection for their honour: parents and other ascending kin; clergy of the Christian faith; state and local government officials; military guard; a leader of a foreign state or a diplomatic representative, as well as captains of steamships or seagoing vessels, and prison guard officials while performing their duties of office. ${ }^{40}$ The Penal Law of 1933, in turn, worded the same idea more laconically: who has injured honour, if it can be recognised as being qualified as to the injured person, shall be punishable by prison sentence. ${ }^{41}$

In Latvia, during the parliamentary period, the alignment of freedom of speech and protection of honour was differentiated, depending on the accused and the victim. The boundaries of freedom of speech were guarded stricter if it was targeting persons who had certain power or had a higher social status. In such cases, the law

36 Mincs, P. Krimināltiesỉbas ... [Criminal Law ...], p. 304.

37 Sodu likums ar komentāriem ... [Penal Law with Commentaries ...], p. 250, note 8 (1923. g. 16. oktobra spriedums Rubina lietā) [(Judgement of 16 October 1923 in Rubin's Case)].

38 Ibid., p. 252, note 22 (1935. g. 4. maija spriedums Dombrovskas lietā) [(Judgement of 4 May 1935 in Dombrovska's Case)].

39 Ibid., p. 252, note 17 (1929. g. 30. novembra spriedums Pilečinas lietā) [(Judgement of 30 November 1929 in Pilečina’s Case)].

40 Article 532 of the Penal Law of 1903.

41 Article 511 of the Penal Law of 1933. 
provided for stricter penalties. Likewise, stricter sanctions were defined in those cases of defamation when a person's honour was undermined in the eyes of peers. ${ }^{42}$

\subsection{Delimiting Freedom of Speech and a Person's Honour in Civil Law}

The civil law limits to freedom of speech were defined in Chapter III of the Collection of Baltic Local Laws. ${ }^{43}$ Only two articles pertained to the protection of honour, included in Section 19 "Claims following from special types of prohibited activities", its Sub-section 3, entitled "Compensation for Injury of Honour". Article 4560 of the Civil Law provided: "An injury to honour, apart from its criminal law consequences, gives the victim only the right to demand the perpetrator to retract his works or to ask for forgiveness; but pecuniary compensation, decided on by the court, he receives only if the injury has caused actual loss or lost profit to him." Article 4561 set a shortened prescription period for such claims - one year. ${ }^{44}$ It must be noted that Article 4560, in unchanged wording, was in force since 1864, when the collection of civil laws was approved. Friedrich Georg von Bunge, the codifier of the Baltic private law, indicated several sources of law for this article - references were made to the Estonian Knightly Law and Land law, the Statute of Kurzeme, the Statute of Piltene, the Laws of Riga City, the Laws of Lübeck City, Regulation of German Supreme Court of 1555, and, finally, to the customary law. ${ }^{45}$ For example, para. 218 of the Statute of Kurzeme, referred to, was included in the section "On Offences and Punishments" and provided: "Those who have caused oral or written injustice once, shall issue retraction, if unable to compose it, shall repay its value; if they have acted so repeatedly, they shall fall into disrepute." ${ }^{36}$

$\mathrm{H}$. Blese questioned the significance of civil law protection of honour, noting that injury to honour or insult "in the current times are of interest only for lawyers specialising in criminal law." ${ }^{\prime 37}$ He maintained that not a single case was known where this article of civil laws had been applied in the last decades - neither the Latvian Senate nor the former Russian Senate had made any statements about

42 For example, the Penal Law of 1933 provided that in the case of insult the perpetrator should be punished by arrest or a monetary fine, not exceeding 550 Lats. However, in all cases of defamation various penalties involving deprivation of liberty were envisaged.

43 Vietējo civillikumu kopojums (Vietējo likumu kopojuma III. daḷa). Tulkojums ar pārgrozījumiem un papildinājumiem, kas izdoti lỉdz 1917. g. 31. decembrim, un ar dažiem paskaidrojumiem. Tieslietu ministrijas sevišķas komisijas sagatavojumā [Collection of Local Civil Laws (Part III of the Collection of Local Laws). Translation with Amendments and Additions Issued before 31 December 1917, and with Some Explanations. Prepared by the Special Committee of the Ministry of Justice]. Riga: Valtera un Rapas akciju sabiedriba, 1928.

44 Article 4561 of Part III of CBLL was expressed in this wording by the Regulation of 28 August 1924 Regulation on Revoking the Difference in the Prescription Period Existing in the Laws of Vidzeme and Kurzeme (Valdības Vèstnesis, No. 206, 11.09.1924). The territorial particularism was revoked by this amendment - the special provision of Kurzeme regarding the prescription period of six months was revoked. It needs to be added that this prescription period had been in force in Kurzeme at least from the beginning of the $17^{\text {th }}$ century (such was set in para. 145 of the Statute of Kurzeme (1617).

45 Liv-, Est- und Curlaendisches Privatrecht. Zusammengestellt auf Befehl des Herrn und Keisers Alexander II. St. Petersburg: Buchdruckerei der Zweiten Abtheilung Seiner Keiserlichen Majestät Eigener Kanzlei, 1864.

46 Kurzemes un Zemgales muižnieku tiesibas un likumi jeb Kurzemes statūti [The Rights and Laws of Kurzeme and Zemgale Nobility or the Statute of Kurzeme]. In: Latvijas tiesību avoti. Teksti un komentāri. 2. sējums. Poḷu un zviedru laiku tiesību avoti (1561-1795) [Sources of Latvian Law. Texts and Commentaries. Volume 2. Sources of Law of Polish and Swedish Times (1561-1795)]. Edited by Dr. hist. Blūzma, V. Rīga: Juridiskā koledža, 2006.

47 Blese, H. Goda aizskaršana civiltiesību laukā [Injury to Honour in the Area of Civil Law]. Jurists, No. 3/4(81/82), 1937, column 65. 
this legal provision. Moreover, already in 1871, J. Schiemann, the advocate of the Courland High Manorial Court, had expressed doubts regarding the validity of this legal institution. His main argument had been that the particular provision of civil law should be deemed as being revoked by providing regulation with the same content in the penal laws. ${ }^{48}$ Commenting on the motives for applying the Penal Law of 1903, Nikolai Tagantsev explained that the double prosecution for the injury to honour, which had existed in the Russian laws, had to be eliminated. Therefore, the civil law compensation for the injury to honour had been revoked, leaving only the criminal prosecution. Compensation for the injury to honour as a private penalty (poena privata) was based on a differential understanding of honour, i.e., it was intended for the protection of the honour of service, family or estate. However, by introducing the unified understanding of personal honour, the State has committed itself to protect this personal benefit on the same terms as the State already protects a person's health or freedom. ${ }^{49}$ Hence, in creating the legal regulation, the legislator's aim had been to establish effective protection for a person's honour, but the impact that this regulation had on a person's freedom of speech in general had not been identified yet or, at least, was not considered to be noteworthy. Although, formally, the particular article of the Baltic Civil Laws was valid, the legal doctrine of the time and also the case law showed that the criminal regulation was considered to be the main mechanism for the protection of honour and, thus, the threat of punishment as the boundary-mark for a person's discretion. ${ }^{50}$

\section{Legal Framework for Freedom of the Press}

Freedom of the press is to be viewed as the public aspect of freedom of speech. ${ }^{51}$ Therefore, both during the existence of the Russian Empire and in the newly established Republic of Latvia, freedom of the press received more attention than the private manifestations of freedom of speech. The Latvian legislator was considerably more active in the area of regulating freedom of the press.

48 Blese, $H$. Goda aizskaršana civiltiesību laukā [Injury to Honour in the Area of Civil Law]. Jurists, No. 3/4(81/82), 1937, column 65-66.

49 Ugolovnoe ulozhenie 22 marta 1903 g.: s" motivami, izvlechennymi iz ob"jasnitel'noj zapiski redakcionnoj komissii, predstavlenija Min. justicii v" Gosudarstvennyj Sovet i zhurnalov" - osobogo soveshhanija, osobogo prisutstvija departamentov" i obshhego sobranija Gosudarstvennogo Soveta, a ravno s" ob"jasnenijami k" dopolnitel'nym" uzakonenijam" i izvlechenijami iz" reshenij Ugolovnago kassacionnago departamenta i obshhago sobranija Pravitel'stvujushhego senata i Glavnago voennago suda kasatel'no vvedennyh" v" dejstvie v" Rossii statej. Po izdanijam N. S. Taganceva [Criminal Code of 22 March 1903: with motives, extracted from the explanatory note of the editorial commission, the presentation of Min. Justice to the State Council and magazines - a special meeting, a special presence of departments and the general meeting of the State Council, as well as explanations for additional legalizations and extracts from the decisions of the Criminal Cassation Department and the general meeting of the Government Senate and the Main Military Court regarding the articles implemented in Russia. According to the publications of N. S. Tagantsev]. Edited by a member of the advisory board at the Ministry of Justice Jacobi, P. N. Riga: Leta, 1922, pp. 1088-1089.

50 It must be added that due to the prevailing significance of penal law, this norm was not transferred to the Civil Law of 1937, leaving the demarcation of boundaries between honour and freedom of speech only within the framework of the Penal Law. Upon reinstating the Latvian Civil Law in 1992, the Supreme Council eliminated this deficiency, adding Section 23521 to this law. Whereas in 2009, the elements of the crime of injury to honour [insult] was excluded from the Criminal Law (Section 156), the reasons started for this step was the need to prevent overlapping with the civil law protection of honour.

51 Kučs, A. Komentārs Satversmes 100. pantam [Commentary on Article 100 of the Satversme.], p. 359. 
Pursuant to the Law on Leaving the Former Laws of Russia in Force in Latvia, adopted by the People's Council on 5 December $1919^{52}$, up to 1924, Regulation on Censorship and the Press (Vol. 16 of the Collection of Laws of Russian Empire) of 1890, with further amendments of 1906, 1912, as well as additions adopted by the Russian Provisional Government on 27 April and 12 July of 1917, was formally in force in Latvia. Historian Gints Zelmenis has researched that, actually, during the first years of its existence, in the Republic of Latvia the area of the press had been regulated by various orders by the Minister for the Interior and government regulations. ${ }^{53}$ Thus, actually continuing the traditions of the former Russian Empire of limiting freedom of speech in emergency conditions, from 1919 to 1921 wartime censorship existed in Latvia. ${ }^{54}$ Moreover, regulating the exercise of this freedom was transferred into the competence of the executive power.

The author does not aim to research the nature and intensity of limitations to civil freedoms during war or any other emergency conditions, which, clearly, change the balance between various values under legal protection, therefore the article focuses on the general regulations, adopted in the legislative procedure of normal (peacetime) circumstances. The following four are considered to be the most important regulatory enactments, shaping the framework of freedom of the press during the period researched: Law on the Press of 1 February $1924,{ }^{55}$ Law on the Productions of Printing Undertakings, Libraries and Reading Rooms of 11 November $1924^{56}$ and Law on Adjudicating Matters of the Press of 11 November 1924 (formally these were amendments to the Criminal Procedure Statute), ${ }^{57}$ as well as Regulation on Protecting the Youth Against Third-Rate and Obscene Literature of 26 April $1927^{58}$, issued in the procedure set out in Article 81 of the Satversme of the Republic of Latvia. Legal regulation defined two types of limits to freedom of the press: 1) personal - by restricting by law the circle of persons who were responsible for disseminating information; 2) substantive - envisaging restrictions or prohibition to disseminate information with certain content.

\subsection{Personal Limits to Freedom of the Press}

In the newly established Republic of Latvia, the work on the legal framework for freedom of the press lasted several years. The government had submitted the new draft legal regulation on the press already to the Constitutional Assembly, but it was never examined at the plenary session. ${ }^{59}$ The new law on the press was adopted by the first convocation of the Saeima at the beginning of 1924. Bruno Kalniņš, the

52 Likumu un valdības rīkojumu krājums [Collection of Laws and Government Orders], issue 13, No. 154, 31.12.1919, p. 170.

53 Zelmenis, G. Cenzūra un to reglamentējošā likumdošana Latvijā (1918-1934) [Censorship and Regulatory Legislation in the Republic of Latvia (1918-1934)]. Latvijas Vēstures Institūta Žurnāls, No. 4(85), 2012, p. 80. Available: https://www.lvi.lu.lv/lv/LVIZ_2012_files/4numurs/G_Zelmenis_ Cenzura_LVIZ_2012_4.pdf [last viewed 26.03.2021].

54 By the order of the Commander-in-Chief of 29 July No. 16, on the basis of the Cabinet Decision of 28 July, starting with 29 July, the previous wartime censorship was introduced with respect to all periodicals in the counties of Rìga, Cēsis, Valmiera and Valka (Latvijas Sargs, No. 99, 30.07.1919, p. 2). The wartime censorship was revoked on 25 March 1921 (Strädnieku Avize, No. 69(574), 27.03.1921,p. 1).

55 Valdïbas Vēstnesis, No. 35, 12.02.1924.

56 Valdïbas Vēstnesis, No. 257, 11.11.1924.

57 Ibid.

58 Valdïbas Vēstnesis, No. 92, 28.04.1927.

59 Treijs, R. Par preses brīvību, pret cenzūru [For Freedom of the Press, Against Censorship]. Latvijas Vēstnesis, No. 41/42, 12.02.1999. Available: https://www.vestnesis.lv/ta/id/21748 [last viewed 27.03.2021]. 
rapporteur on the draft law, underscored that the responsible committee had based the new law on principles that complied with the contemporary understanding of democracy in Western Europe. ${ }^{60}$

The first article of the Law on the Press, in accordance with the understanding of fundamental rights of the time, provided: "Freedom of the press shall exist in Latvia within the limits of this law". Thus, the law was not viewed as the restrain of freedom but rather the creator of freedom of the press. Therefore, we also do not see concern in the parliamentary debates about this law, whether the law would place disproportional restrictions on the individual's freedom of speech; instead, the discussion focuses on the persons who should be granted the right to become involved in dissemination of information, i.e., to be managing editors and publishers. The second article of the Law on the Press defined the circle of subjects, who could be the managing editors and publishers in Latvia - the qualification of citizenship and age (at least 25 years) was set, likewise, this right was denied to persons whose rights had been restricted by a court's judgement or against whom criminal prosecution had been initiated for crimes that entailed loss or restriction of rights. If a legal person wanted to become a publisher, the same requirements were applicable to its representative. A foreign citizen could become a managing editor or publisher only with permission by the Minister for the Interior. Moreover, the law required the managing editor to reside permanently in Latvia.

A Cabinet member (in difference to a member of the Saeima) was prohibited from being a managing editor. When the draft law was discussed at the Saeima, Arveds Bergs criticised sharply the absence of such restriction with respect to members of the Saeima. He was worried that a managing editor, protected by the deputy's immunity, could act arbitrarily and injure the honour of other persons with impunity. He also pointed to a case, where the Saeima did not allow initiation of legal proceedings against one editor on the basis of a private complaint. ${ }^{61}$ However, five years later the Law on the Press was amended, prohibiting also members of the Saeima from becoming the managing editor of a periodical. ${ }^{62}$ This amendment was adopted to rule out the slightest possibility that a member of the Saeima, as a managing editor, could escape criminal liability for injuring other persons' honour. ${ }^{63}$

To monitor the personal limits to freedom of the press, described above, a system for registering periodicals was introduced. To establish a periodical, an application had to be submitted to the Ministry of the Interior, indicating: a) title of the publication and indications regarding its nature (political, literary, technical, etc.); b) information about the managing editor and the publisher; c) printing house, where it will be printed; d) procedure (frequency) of publication; e) language of the

60 Latvijas Republikas Saeimas III sesijas 17. sēde 1923. gada 12 . decembrī $\left[17^{\text {th }}\right.$ sitting of III session of the Saeima of the Republic of Latvia on 12 December 1923]. In: Latvijas Republikas Saeimas stenogrammas. III sesija (19 sēdes) (no 1923. gada 9. oktobra līdz 1923. gada 14. decembrim) [Transcripts of the III Saeima of the Republic of Latvia (19) sittings (from 9 October 1923 to 14 December 1923)]. Rīga: Latvijas Republikas Saeimas izdevums, [s. a.], column 435.

61 Latvijas Republikas Saeimas III sesijas 17. sēde 1923. gada 12. decembri $\left[17^{\text {th }}\right.$ sitting of III session of the Saeima of the Republic of Latvia on 12 December 1923], column 439-440.

62 Pārgrozījums Preses likumā [Amendments to the Law on the Press]. Valdības Vēstnesis, No. 109, 17.05.1929.

63 Latvijas Republikas III Saeimas III sesijas 15. sēde 3. maijā 1929. gadā [ $15^{\text {th }}$ sitting of III session of the Saeima of the Republic of Latvia on 3 May 1929]. In: Latvijas Republikas III Saeimas stenogrammas. III sesija, 1929. gads [Transcripts of III Saeima of the Republic of Latvia. III session. 1929]. Riga: Latvijas Republikas Saeimas izdevums, [s. a.], column 468-469. 
periodical. ${ }^{64}$ The Ministry of the Interior had a fortnight to verify that there were no statutory obstacles to establishing the periodical and had to make a corresponding declaration. If during the operation of the periodical, the publisher wanted to change any of the circumstances indicated in the initial application, as well as in the case of the managing editor's or the publisher's death, an additional declaration by the Ministry of the Interior had to be requested. ${ }^{65}$

An analogous system of application or registration was established also by the Law on Trading in Productions of Printing Undertakings, Libraries and Reading Rooms. The head of the respective county or the municipal prefect had to be informed about the establishment of a publishing house, a store of products of printing undertakings (book-stores), opening of a library or a reading room, as well as taking up door-to-door sale of books by submitting an application, similar in content to the one envisaged by the Law on the Press. No later than within a fortnight after the receipt of this application, the applicant was issued a declaration, which had to be permanently present in the applicant's undertaking. The declaration was not issued if the responsible person of the undertaking or the door-to-door salesman: a) could not indicate a permanent place of residence in Latvia; b) had not attained the age of 21; c) his rights were restricted by a court's judgement. ${ }^{66}$ Compared to the requirements set for the managing editor and publisher, the ones set for the owner of a bookstore, a library or a reading room were slightly lower, i.e., the required age was lower and initiated criminal prosecution was excluded as the cause for dismissal.

Although the law did not allow anyone, freely and without prior application, to become an editor of a periodical, open one's own bookstore or even sell books by going door-to-door, the legislator's main aim was to ensure proper functioning of the liability mechanism in instances where freedom of the press was violated. The Law on the Press required submitting, together with the application to the Minister for the Interior, the editor's statement that he assumed responsibility for editing the periodical or a certain part of it. The manager in charge of a publishing house, a store selling the products of printing undertakings, a library or a reading room had to submit a written statement that he assumed responsibility. Information about the names and places of residence of persons involved in the publishing and circulation of periodicals and books was necessary to preclude violations of other persons' rights (injury to their honour) or committing other violations of rights with impunity under the cover of anonymity.

\subsection{The Substantial Limits to Freedom of the Press}

Substantial limits to freedom of the press were defined by the Law on the Press, Law on Trade in Productions of Printing Undertakings, on Libraries and Reading Rooms, and Regulation on Protecting the Youth against Third-Rate and Obscene Literature. These restrictions varied from restrictions to dissemination of information up to prohibition to store editions with certain content - the prohibited editions.

Pursuant to the Law on the Press, without permission of the chairperson of the said institution, it was prohibited to report on a closed sitting of the Saeima and court hearings in camera. In defamation cases, where the defendant did not have

64 1924. gada 1. februāra Preses likums [Law on the Press of 1 February 1924], Article 4.

65 Ibid., Articles 5-8.

66 Likums par tirdzniecību ar poligrāfisko iestāžu ražojumiem, par bibliotēkām un lasītavām [Law on Trade in Productions of Printing Undertakings, on Libraries and Reading Rooms: Law of the Republic of Latvia], Article 1-4. 
the right to prove the truthfulness of his insult, the press could report only on the court's resolution, but reporting on other facts of the case could be allowed by the court's president only on the basis of the defendant's request. Prior to the court hearing or termination of the case, it was prohibited to report on inquisitory or pre-trial investigation materials, as well as on the content of the indictment. The law also allowed the Minister for the Interior together with the Minister for War during war or imminent war to prohibit for a certain period reporting in the press on the facilities and equipment of Latvia's military or maritime forces, as well as for guarding the external border of the State. These substantial limitations, defined in the Law on the Press, can be grouped in three trends, which reveal the aim of these restrictions: 1) publication of restricted access information only with permission for it; 2) not publishing information obtained in criminal procedure (in the name of the presumption of innocence); 3) not disseminating news of military nature (in the interests of national defence).

A significant and, at the same time, rather vague restriction on freedom of the press was included in Article 18 of the Law on the Press, which granted to the Minister for the Interior the right to confiscate productions of printing undertakings entering from abroad, as well as to prohibit bringing certain periodicals in from abroad if their content was criminal in accordance with Latvian laws. It has to be added, however, that the law established also three exceptions when confiscation was inadmissible. The substantial restrictions could not limit the range of publications accessible to the legislator, institutions of higher education and research and organisations, as well as the press (editorial boards of newspapers). The same idea of substantial restrictions was continued in Article 10 of the Law on Trading in Productions of Printing Undertakings, Libraries and Reading Rooms: "Stores, warehouses and collections of productions of printing undertakings, libraries and reading rooms, as well as door-to-door salesmen may not store and disseminate books that are prohibited in Latvia, as well as other productions of printing undertakings, the lists of which shall be published in "Government Herald"”. The concept of "prohibited books" appears in this law, but its content lacked strict definition. To prevent this, this legal provision was applied in conjunction with the Law on the Press. Therefore, the Minister for the Interior, publishing several times in "Government Herald" the lists of books prohibited in Latvia, also referred to Article 18 of the Law on the Press and used as substantiation Article 10 of the Law on Trading in Productions of Printing Undertakings, Libraries and Reading Rooms. In accordance with this procedure, the first list of prohibited books was published in "Government Herald" already on 1 December 1924, prohibiting to bring into Latvia and disseminate 180 specific titles. ${ }^{67}$ When reading this list of prohibited books, we see that, predominantly, the Minister for the Interior had recognised as having criminal content publications of anarchistic, communist or monarchic orientation. Thus, the concept "criminal" was interpreted in the context of crimes against the State (against the lawful power).

A mechanism similar to the lists of prohibited books was established by the Cabinet Regulation of 26 April 1927. The circulation of certain editions was restricted with the aim of protecting the youth against third-rate and obscene literature. The Regulation provided that the Ministers for Education and for the Interior established a special committee, which decided on the publications to be

67 Valdības iestāžu paziņojumi [Aizliegto grāmatu saraksts] [Announcements by Governmental Institutions [List of Prohibited Books]]. Valdības Vēstnesis, No. 273, 01.12.1924. 
included in the list of third-rate and obscene literature. The committee's decisions were approved by the Minister for Education and also these were announced in "Government Herald". The publications included in this list could not be displayed openly or offered at bookstores, kiosks, public spaces, they could not be handed out to persons below the age of 18 and kept in school and youth libraries. The first such list of literature, harmful for youth, was approved on 19 July 1927 by the outstanding Latvian poet and thinker Jānis Rainis, being the Minister for Education at the time. ${ }^{68}$ Although also in this case vague legal terms were used in the legal provisions - third-rate and obscene literature, the more specific aim of this legal regulation helped to fill it with content, i.e., protecting immature personalities from literature detrimental to their development, inter alia, proper socialisation.

Compliance with both the Law on the Press and the Law on Trade in Productions of Printing Undertakings, on Libraries and Reading Rooms was guaranteed by including the respective elements of the criminal offences in penal laws. Chapter fifteen of the Penal Law of 1903 (Art. 292-903) was dedicated to infringements of the rules on supervision of the press Also, in the Penal Law of 1933 criminal offences in the area of the press were included in a separate chapter - the nineteenth, "Violations of the rules on supervising printing houses and other printing undertakings, the press, libraries, reading rooms, performances and cinematographs" (Art. 317-332). P. Mincs explained that all these infringements placed in this chapter had in common the fact that they all targeted regulations, the aim of which was to prevent the abuse of such measures or to ensure prosecution for the abuse of such measures which, being technically easier, allow addressing an unlimited circle of persons. ${ }^{69}$ Thus, the rules included in this chapter did not directly protect national, social or individual interests, which would be damaged by abusing freedom of the press, but were aimed at the formal side of exercising freedom of the press. The objective of these elements of offences was to ensure functioning of the system for supervising the press, which would be an important preventive measure for protecting other lawful interests. This leads to the conclusion that the boundaries of freedom of speech, in their public aspect, were strictly guarded, irrespectively if the violation of them caused damage to the State or a private person.

\section{Summary}

1. The first two provisional constitutions of the Republic of Latvia guaranteed expressis verbis freedom of the press and freedom of speech. The Fundamental Laws of the Russian Empire of 1906, the unadopted Part II of the Satversme of the Republic of Latvia, as well as the contemporary dogmatics of fundamental rights recognised that freedom of speech, as a broader concept, included also freedom of the press. Therefore, the author examines these two civil freedoms, referred to separately in the first constitutional legal acts of Latvia, as two manifestations of freedom of speech.

2. Freedom of speech was not viewed as an inalienable natural right of citizens but as a subjective public right, granted by the State, which existed only within the limits set in law. The State had greater discretion in developing the legal regulation on freedom of speech. It was not obliged to justify

68 Sēnalu un neḳitrības literatūras saraksts Nr. 1 [List of Third-Rate and Obscene Literature No. 1]. Valdības Vēstnesis, No. 157, 20.07.1927.

69 Mincs, P. Krimināltiesïbas ... [Criminal Law ...], p. 135. 
intervening in an individual's freedom or examine its proportionality because the existence of freedom of speech outside the framework defined in law was not recognised.

3. There were dual limits to freedom of speech: 1) freedom of speech ended where injury to another person's honour began; 2) due to its public nature, freedom of the press could be exercised in the procedure and within the framework established by law. In both cases, violation of the limits of freedom of speech entailed penalty. In the case where honour was injured, the penalty depended on the victim's (the insulted person's) will because in these cases law envisaged the procedure of private prosecution. However, when the limits to freedom of the press had been violated, the procedure of public prosecution was applicable, moreover, the elements of criminal offences were formal - a person could be punished for violating regulations on monitoring the press irrespectively of the fact whether this infringement of rights caused damage to the national, social or individual interests.

4. Demarcation of one person's freedom of speech and the other person's honour in the Republic of Latvia, compared to the previous period in legal history, remained almost unaltered. The reason for this was the close link between the concept of honour and public view on morals and customs. Honour was strictly guarded, insulting or offensive exercise of freedom of speech entailed criminal liability, but the civil law protection of honour was relegated to the second place. Honour as a legal benefit was more highly valued than freedom of speech, whereas the differentiated criminal liability for injuries to honour (depending on the legal and social status of the persons involved) showed that democratic values (in particular, equality) were slowly taking root in society.

5. Compared to the previous period of legal history, the framework of freedom of the press was continually broadened in the Republic of Latvia. Legal regulation defined two types of limits to freedom of the press: 1) personal - by restricting by law the circle of persons who were responsible for disseminating information; 2) substantive - envisaging restrictions or prohibition to disseminate information with certain content. In establishing the personal restrictions on freedom of the press, the legislator wanted to ensure proper functioning of the liability mechanism in instances where freedom of the press was violated. The substantive restrictions, in turn, were set for reaching various aims - starting with non-disclosure of information of military nature for the sake of national security up to making lists of obscene and third-rate literature to protect children and youth from inappropriate content. The creation of lists of prohibited books and third-rate and obscene literature allowed within the framework of freedom of the press showed that State, nevertheless, did not rely on individuals exercising freedom of speech properly, therefore paternalistic treatment of its citizens was not unknown to the new democratic republic.

\section{Sources}

\section{Bibliography}

1. Blese, H. Goda aizskaršana civiltiesību laukā [Injury to Honour in the Area of Civil Law]. Jurists, No. 3/4(81/82), 1937, column 65-68.

2. Hamkova, D. Goda un cieņas krimināltiesiskā aizsardzība. Promocijas darbs [Doctoral thesis "Criminal Law Protection of Honour and Dignity"]. Rīga: Latvijas Universitāte, 2009. 
Available: http://dspace.lu.lv/dspace/bitstream/handle/7/5038/13775-Diana_Hamkova_2009. pdf? sequence $=1$ \&isAllowed $=y$ [last viewed 21.03.2021].

3. Kelsen, $H$. Reine Rechtslehre. Studienausgabe der 1. Auflage 1934. Herausgegeben von Jestaedt, M. Tübingen: Mohr Siebeck, 2008.

4. Konstitucionālo tiesîbu komisijas viedoklis "Par Latvijas valsts konstitucionālajiem pamatiem un neaizskaramo Satversmes kodolu" [Opinion of the Constitutional Law Committee "On the Constitutional Foundation of the State of Latvia and the Inviolable Core of the Satversme"]. Available: http://blogi.lu.lv/tzpi/files/2017/03/17092012_Viedoklis_2.pdf [last viewed 20.03.2021].

5. Kučs, A. Komentārs Satversmes 100. pantam [Commentary on Article 100 of the Satversme]. In: Latvijas Republikas Satversmes komentāri. VIII nodalıa. Cilvēka pamattiesības [Commentaries on the Satversme of the Republic of Latvia. Chapter VIII. Fundamental Human Rights]. Collective of authors, scientific ed. Prof. Balodis, R. Rīga: Latvijas Vēstnesis, 2011.

6. K. V. Goda aizskaršana [Injury to Honour]. Tieslietu Ministrijas Vēstnesis, No. 9, 1926, pp. 354-360.

7. Lazdiñ̌s, J. Rechtspolitische Besonderheiten bei der entstehung des lettischen Staates und seiner Verfassung. Journal of the University of Latvia. Law, No. 7, 2014, pp. 9-20.

8. Mincs, P. Krimināltiesības. Sevišķā dal̦a [Criminal Law. Special Part]. With Commentaries by Liholaja, V. Rìga: Tiesu namu aǵentūra, 2005.

9. Nepārtrauktības doktrīna Latvijas vēstures kontekstā [The State Continuity Doctrine in the Context of Latvia’s History]. Collective of authors, scientific ed. Prof. Jundzis, T. Rīga: Latvijas Zinātṇu akadēmijas Baltijas stratēǵisko pètījumu centrs, 2017.

10. Osipova, S. Latvijas Republikas konstitucionālā identitāte Satversmes tiesas spriedumos [The Constitutional Identity of the Republic of Latvia in the Constitutional Court's Judgements]. In: Osipova, S. Nācija, valoda, tiesiska valsts: ceḷā uz rītdienu [Nation, Language, Rule-of-Law State: Towards Tomorrow]. Rìga: Tiesu namu ag̀entūra, 2020.

11. Osipova, S. Tautas gars, pamatnorma un konstitucionālā identitāte [The Spirit of the Nation, Basic Norm, and the Constitutional Identity]. In: Osipova, S. Nācija, valoda, tiesiska valsts: ceḷā uz rītdienu [Nation, Language, Rule-of-Law State: Towards Tomorrow]. Rīga: Tiesu namu aǵentūra, 2020.

12. Pleps, J. Komentārs Satversmes 116. pantam [Commentary on Article 16 of the Satversme]. In: Latvijas Republikas Satversmes komentāri. VIII nodaḷa. Cilvēka pamattiesības [Commentaries on the Satversme of the Republic of Latvia. Chapter VIII. Fundamental Human Rights]. Collective of authors, scientific ed. Prof. Balodis, R. Rìga: Latvijas Vēstnesis, 2011.

13. Rubenis, A. Imanuels Kants. Ķerras stūmēja mēgeinājums tuvoties karalim [Immanuel Kant. The Wheelbarrow Pusher's Attempt to Approach the King]. Riga: Minerva, 2006.

14. Schöbener, B., Knauff, M. Allgemeine Staatslehre. 2. Aufl. München: Verlag C. H. Beck, 2013.

15. Sodu likums ar komentāriem - izvilkumiem no Senāta Kriminālā kasācijas departamenta spriedumiem un ar alfabētisko un salìdzināmiem rādītājiem [Penal Law with Commentaries - Extracts from the Judgements by the Senate Criminal Cassation Department with an Alphabetic and Comparative Indexes]. Complied by Mincs, P., Lauva, J. $2^{\text {nd }}$ edition. Rīga: Valsts tipogrāfijas izdevums, 1938.

16. 1903. gada 22. marta Sodu likumi. Tulkojums ar paskaidrojumiem un ar motīviem par Latvijas valdỉbas laikā izdotiem grozijjumiem. Tieslietu ministrijas sevišķas komisijas sagatavojumā [Penal Laws of 22 March 1903. Translation with explanation and reasons for amendments introduced during the period of the Latvian Government. Prepared by the special committee of the Ministry of Justice]. $3^{\text {rd }}$ edition. Rìga: Valsts tipogrāifia, 1930.

17. 1933. gada 24. aprịla Sodu likums ar likumdošanas motīviem un sỉkiem komentāriem [Penal Law of 24 April 1933 with Legislative Reasoning and Detailed Commentaries]. Complied by Mincs, P., Ehlerss, H., Jakobi, P., Lauva, J. Repeated edition. Rīga: SIA “Grāmata", 2016.

18. Švābe, A. Mūsu sodu likumu valoda [Language of our Penal Laws]. Tieslietu Ministrijas Vēstnesis, No. 6-8, 1933, pp. 129-144.

19. Treijs, R. Par preses brīvibu, pret cenzūru [For Freedom of the Press, Against Censorship]. Latvijas Vèstnesis, No. 41/42, 12.02.1999. Available: https://www.vestnesis.lv/ta/id/21748 [last viewed 27.03.2021].

20. Ugolovnoe ulozhenie 22 marta 1903 g.: s" motivami, izvlechennymi iz ob"jasnitel'noj zapiski redakcionnoj komissii, predstavlenija Min. justicii v" Gosudarstvennyj Sovet i zhurnalov" - osobogo soveshhanija, osobogo prisutstvija departamentov" i obshhego sobranija Gosudarstvennogo Soveta, a ravno s" ob"jasnenijami k" dopolnitel'nym" uzakonenijam" i izvlechenijami iz" reshenij Ugolovnago kassacionnago departamenta i obshhago sobranija Pravitel'stvujushhego senata i Glavnago voennago suda kasatel'no vvedennyh" v" dejstvie v" Rossii statej. Po izdanijam N. S. Taganceva [Criminal Code of 22 March 1903: with motives, extracted from the explanatory note of the editorial commission, the presentation of Min. Justice to the State Council and magazines - a special meeting, a special presence of departments and the general meeting of the State Council, as well as explanations for additional legalizations and extracts from the decisions of the Criminal Cassation Department and 
the general meeting of the Government Senate and the Main Military Court regarding the articles implemented in Russia. According to the publications of N. S. Tagantsev]. Edited by a member of the advisory board at the Ministry of Justice Jacobi, P. N. Riga: Leta, 1922.

21. Zelmenis, G. Cenzūra un to reglamentējošā likumdošana Latvijā (1918-1934) [Censorship and Regulatory Legislation in the Republic of Latvia (1918-1934)]. Latvijas Vēstures Institūta Žurnāls, No. 4(85), 2012, pp. 79-104. Available: https://www.lvi.lu.lv/lv/LVIZ_2012_files/4numurs/G_ Zelmenis_Cenzura_LVIZ_2012_4.pdf [last viewed 26.03.2021].

\section{Normative Acts}

1. Latvijas Republikas Satversme [Constitution of the Republic of Latvia]: Law of the Republic of Latvia. Valdības Vēstnesis, No. 141, 30.06.1922.

2. Liv-, Est- und Curlaendisches Privatrecht. Zusammengestellt auf Befehl des Herrn und Keisers Alexander II. St. Petersburg: Buchdruckerei der Zweiten Abtheilung Seiner Keiserlichen Majestät Eigener Kanzlei, 1864.

3. Latvijas Tautas padomes politiskā platforma [The Political Platform of the Latvian People's Council]: The Provisional Law of the Republic of Latvia. Pagaidu Valdības Vèstnesis, No. 1, 14(1)1918.

4. Pagaidu nolikums par Latvijas tiesām un tiesāšanas kārtību [Provisional Regulation on Latvian Courts and Procedure of Administering Justice]: Law of the Republic of Latvia. Pagaidu Valdības Vēstnesis, No. 1, 14(1)1918.

5. Likums par agrāko Krievijas likumu spēkā atstāšanu Latvijā [Law on Leaving the Former Laws of Russia in Force in Latvia]: Law of the Republic of Latvia. Likumu un valdības rìkojumu krājums, issue 13, No. 154, 31.12.1919.

6. Latvijas valsts iekārtas pagaidu noteikumi [Provisional Regulation on the Order of the Latvian State]: Law of the Republic of Latvia. Valdìbas Vēstnesis, No. 123, 03.06.1920.

7. Preses likums [Law on the Press]: Law of the Republic of Latvia. Valdìbas Vèstnesis, No. 35, 12.02.1924.

8. Noteikumi par Vidzemes un Kurzemes likumos pastāvošā noilguma starpības atcelšanu [Regulation on Revoking the Difference in the Prescription Period Existing in the Laws of Vidzeme and Kurzeme]: Law of the Republic of Latvia. Valdības Vèstnesis, No. 206, 11.09.1924.

9. Likums par tirdzniecību ar poligrāfisko iestāžu ražojumiem, par bibliotēkām un lasītavām [Law on Trade in Productions of Printing Undertakings, on Libraries and Reading Rooms]: Law of the Republic of Latvia. Valdības Vēstnesis, No. 257, 11.11.1924.

10. Likums par preses lietu tiesāšanas kārtību [Law on the Procedure for Adjudicating Matters of the Press]: Law of the Republic of Latvia. Valdības Vēstnesis, No. 257, 11.11.1924.

11. Noteikumi par jaunatnes pasargāšanu no sēnalu un neḳītrību literatūras [Regulation on Protecting the Youth against Third-Rate and Obscene Literature]: Regulation of the Republic of Latvia. Valdības Vēstnesis, No. 92, 28.04.1927.

12. Vietējo civillikumu kopojums (Vietējo likumu kopojuma III. daḷa). Tulkojums ar pārgrozījumiem un papildinājumiem, kas izdoti lìdz 1917. g. 31. decembrim, un ar dažiem paskaidrojumiem. Tieslietu ministrijas sevišķas komisijas sagatavojumā [Collection of Local Civil Laws (Part III of the Collection of Local Laws). Translation with Amendments and Additions Issued before 31 December 1917, and with Some Explanations. Prepared by the Special Committee of the Ministry of Justice]. Riga: Valtera un Rapas akciju sabiedrïba, 1928.

13. Pärgrozijums Preses likumā [Amendments to the Law on the Press]: Law of the Republic of Latvia. Valdības Vēstnesis, No. 109, 17.05.1929.

14. Likums par Sodu likuma un Disciplinārsodu likuma ieviešanu [Law on Implementing the Penal Law and Law on Disciplinary Penalties]: Law of the Republic of Latvia. Valdïbas Vèstnesis, No. 138, 27.06.1933.

15. Kurzemes un Zemgales muižnieku tiesības un likumi jeb Kurzemes statūti [The Rights and Laws of Kurzeme and Zemgale Nobility or the Statute of Kurzeme]. In: Latvijas tiesību avoti. Teksti un komentāri. 2. sējums. Poḷu un zviedru laiku tiesību avoti (1561-1795) [Sources of Latvian Law. Texts and Commentaries. Volume 2. Sources of Law of Polish and Swedish Times (1561-1795)]. Edited by Dr. hist. Blūzma, V. Rīga: Juridiskā koledža, 2006.

16. Die Verfassung des Deutschen Reichs [„Weimarer Reichsverfassung“] vom 11. August 1919. Available: http://www.documentarchiv.de/wr/wrv.html [last viewed 23.03.2021].

17. Vysochajshe utverzhdennye Osnovnye Gosudarstvennye Zakony [Supremely Approved Fundamental State Laws]. Complete collection of laws of the Russian Empire, Vol. XXVI, No. 27805. Available: http://www.hist.msu.ru/ER/Etext/apr1906.htm [last viewed 20.03.2021]. 


\section{Other Sources}

1. Latvijas Republikas Satversmes 2. daḷa. Pamatnoteikumi par pilsoṇu tiesībām un pienākumiem (netika pienemta) [Part 2 of the Satversme of the Republic of Latvia. Fundamental Rules on Citizens' Rights and Obligations (was not adopted)]. In: Šilde, $\bar{A}$. Latvijas vēsture. 1914-1940. Valsts tapšana un suverēnā valsts [Latvian history. 1914-1940. State formation and sovereign state]. Stokholma: Daugava, 1976.

2. Satversmes sapulces V sesijas 2. sēdes (1922. gada 18. janvārī) stenogramma [Transcript of the $2^{\text {nd }}$ sitting of V session of the Constitutional Assembly (18 January 1922)]. Available: http://flriga.lu.lv/ tzpi/materiali/Satversmes_sapulces_stenogrammas.pdf [last viewed 20.03.2021].

3. Satversmes sapulces V sesijas 10. sēeses (1922. gada 7. februārī) stenogramma [Transcript of the $10^{\text {th }}$ sitting of V session of the Constitutional Assembly (7 February 1922)]. Available: http://flriga.lu.lv/ tzpi/materiali/Satversmes_sapulces_stenogrammas.pdf [last viewed 20.03.2021].

4. Latvijas Republikas Saeimas III sesijas 17. sēde 1923. gada 12. decembrī $\left[17^{\text {th }}\right.$ sitting of III session of the Saeima of the Republic of Latvia on 12 December 1923]. In: Latvijas Republikas Saeimas stenogrammas. III sesija (19 sēdes) (no 1923. gada 9. oktobra lìdz 1923. gada 14. decembrim). [Transcripts of the III Saeima of the Republic of Latvia (19) sittings (from 9 October 1923 to 14 December 1923)]. Rīga: Latvijas Republikas Saeimas izdevums, [s. a.].

5. Latvijas Republikas III Saeimas III sesijas 15. sēde 3. maijā 1929. gadā [15 ${ }^{\text {th }}$ sitting of III session of the Saeima of the Republic of Latvia on 3 May 1929]. In: Latvijas Republikas III Saeimas stenogrammas. III sesija, 1929. gads [Transcripts of III Saeima of the Republic of Latvia]. Rìga: Latvijas Republikas Saeimas izdevums, [s. a.].

6. Valdības iestāžu paziṇojumi [Aizliegto grāmatu saraksts] [Announcements by Governmental Institutions [List of Prohibited Books]]. Valdības Vēstnesis, No. 273, 01.12.1924.

7. Sēnalu un nekīitrības literatūras saraksts Nr. 1 [List of Third-Rate and Obscene Literature No. 1]. Valdības Vēstnesis, No. 157, 20.07.1927.

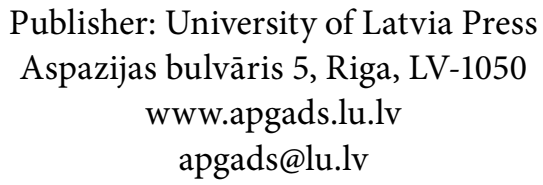

